\title{
Queen Elizabeth I's Progress to Bristol in 1574: An Examination of Expenses
}

Royal visits to provincial towns and cities were by no means a new phenomenon in the sixteenth century, although Queen Elizabeth is the monarch most renowned for her annual progresses. ${ }^{1}$ Progresses functioned principally as opportunities for developing an interactive dialogue between the queen and her subjects. ${ }^{2}$ The queen could assert her authority while for civic hosts, progresses usually accompanied by civic petitions provided an opportunity to strengthen ties to the crown in hope of winning favour. ${ }^{3}$ In 1574 , however, Bristol did not include a petition since the corporation used its entertainments not to appeal to Elizabeth but rather to display gratitude and loyalty. To understand this progress fully we must put into context not only the contemporary political setting but also the nature of Bristol's corporation.

The timing of the queen's visit was of great significance. She arrived only a few days before signing the Treaty of Bristol which renewed trade links between England and Spain. King Philip II of Spain and Lord Burghley, however, had already confirmed this reopening of trade in Madrid on 8 June $1573 .{ }^{4}$ This prior ratification clarifies that the entertainments for the queen were not used as a tool for petitioning her but rather to reflect the city's gratitude by displaying symbolically its military power and loyalty. The corporation made immense efforts to display its thanks, illustrating just how important this agreement was to them. By looking at Bristol's customs accounts and at the corporation itself we can see why the trade agreement would justify the elaborate entertainments.

The records from Bristol's customs accounts and port books highlight just how integral Spanish trade was to the city. The 1563/4 customs accounts show that imports of Spanish wine and iron made up nearly twenty percent of the $£ 12,130$ worth of goods received throughout the whole year. ${ }^{5}$ More importantly, the port books of 1575/6 illuminate why in 1574 the Bristol corporation was so grateful for the renewal of Spanish trade links. The 
port books outwards show that Bristol exported lead and cloth with a value of over $£ 1,723$ to Spanish ports during the year; this figure represents over twenty per cent of all exports that year. ${ }^{6}$ Even more revealing are the imports that year which saw Bristol receiving Spanish wine and olive oil to the value of over $£ 6,500$, forty per cent of the total value of its imports that year. ${ }^{7}$ The clear majority of the remaining imports came from Portugal, making up forty-two per cent of the total imports. ${ }^{8}$ These Portuguese ports would have undoubtedly been harder to access if the queen had not made provision for peaceful trade to resume with Spain. These figures emphasize the economic importance of Bristol's trade with the Iberian peninsula. Indeed, the corporation of Bristol itself was commonly made up of members of the merchant elite. ${ }^{9}$ Such ties between the corporation and Bristol's trade suggest that the members of the corporation who directed the hosting of Elizabeth I might have had additional personal motivation to ensure peaceful trade with Spain. We can confirm this suggestion by looking at the membership of the 1574 corporation, which included the likes of Thomas Aldworth and even the mayor, Thomas Kelke, both of whom were merchants. ${ }^{10}$ The mercantile nature of the corporation reinforces the notion that its members would be keen to ensure the health of Bristol's trade.

Returning to the progress itself, we find a great deal of information in Thomas Churchyard's description of the event. Churchyard, a member of the queen's retinue, recorded all the speeches made throughout the visit, supplementing them with notes outlining the elaborate entertainments. From his account we can learn not only what was said but also what message the entertainments were intended to convey. On the first day the queen was welcomed with speeches and subsequently entertained by an impressive threeday mock battle. Orations during the artificial confrontation outlined an allegory of War, represented by the offensive force, in conflict with Peace, symbolized by the defending fort. The entertainments were littered with speeches interspersed with mock engagements, which even included a naval pursuit up the Avon. The conclusion involved Elizabeth playing the role of adjudicator and presiding over negotiations for a peaceful treaty, evidently to mirror the agreement made with Spain. ${ }^{11}$ The message was clear: an assurance of military strength and loyalty towards the crown in thanks for the queen revitalizing peaceful trade with Iberia. The political and economic context outlined above makes it easy to understand why the corporation presented such an allegory. ${ }^{12}$ Less clear are the lengths to which the corporation went to develop this ceremonial dialogue for communicating such a message. 
The mayor's audit books contain two original documents of receipts and expenses relating to this royal progress, both of which have been transcribed in the Records of Early English Drama for Bristol. These documents help us to understand how the city council, the corporation, went about establishing this discourse.

Previous scholars have tended to use Elizabeth's progress to Bristol only as an example in broader studies. David Bergeron's book on civic pageantry is just one case. ${ }^{13}$ The only historian to look at Bristol in any detail is D.H. Sacks, although he, like others writing on this topic, addresses it solely through one source: Thomas Churchyard's record. ${ }^{14}$ While a valuable primary source, Churchyard's account does not throw light on the funding, cost, or sheer scale of the visit. Only Mary Hill Cole really addresses the finances involved in hosting royal visits. In The Portable Queen she briefly discusses the funding and costs of Elizabethan progresses, and while her work does not include the finances of Bristol's progress, it provides a useful framework for examining these sources. ${ }^{15}$ One of Cole's conclusions is that hosts of royal visits did not have to incur great expense. This finding immediately raises questions with respect to the Bristol progress, since the expenses came to over $£ 1,000 .{ }^{16}$ My examination of the receipts and expenses explores how the corporation came to spend so much.

First, the 'receipts account' helps us to understand the funding of the queen's entertainments. In the receipts account about half of the money appears to be collected from various city districts, totalling $£ 5361 \mathrm{~s} 7 \mathrm{~d}$ of the $£ 1120$ 17s 11d collected. ${ }^{17}$ While the methods used for raising the money are not entirely clear the division into wards suggests that the corporation taxed their citizens to fund the entertainments. While Cole's study includes the example of Ipswich, where a general tax was used to finance the queen's visit, she highlights this method of fundraising as being rare. ${ }^{18}$ In the case of Bristol, however, the money was also likely raised through a special tax. ${ }^{19}$ Despite aldermen likely being assessed at a higher rate than the rest of the citizenry, the fact that all the wards were taxed, combined with the considerable sum collected, highlights how the whole city had been made to invest in the success of the occasion.

The receipts go on to record $£ 200$ from Thomas White's account and $£ 250$ from 'Barstaples Chest'. ${ }^{20}$ White was a prominent member of the Merchant Taylors in London, who upon his death in 1567 bequeathed $£ 2,000$ to the corporation of Bristol so it could purchase land and use the income for charitable purposes. ${ }^{21}$ 'Barstaples Chest' was most likely a similar form 
of charitable fund used by the corporation. While the receipts do not make entirely clear who was donating money, the borrowing of money from reserves implies that the corporation was stretching its resources to the limit. With such a picture painted by the receipts one would expect little to be wasted and every expense was likely scrutinized in detail.

Rather than beginning with a detailed examination of the expenses account, I have categorized the varying costs to help develop a coherent analysis. Cole divides expenses into 'temporary' and 'permanent' costs, the method of categorization adopted and slightly modified here. ${ }^{22}$ Cole's division sits naturally with progresses in general, with the majority of temporary expenditure being for the entertainments during the queen's visit, while permanent expenditure was dominated by improvements to a city's infrastructure.

Cole characterizes 'permanent' costs as investments in a city's future, since they constituted necessary improvements. The queen's arrival thus merely set a deadline for work that was necessary anyway. ${ }^{23}$ The expenses in Bristol suggest, however, that the royal visit did not merely set a deadline. Rather, it shaped the nature and pattern of the investment. The very first entry in the expense account concerns one such cost.

In primis paid for charges of gilting \& paynting the highe crosse and making newe benchys as by thaccompt — Lxvi.li xiii.s vii.d ${ }^{24}$

The payment here of over $£ 66$ is one of the largest in the expenses account and is the biggest 'permanent' fee. Churchyard's account tells us that 'At the hie Crosse in a disguised manner stoed Faem' 25 who delivered one of the recorded speeches. Orations such as these facilitated the desired ceremonial dialogue between city and monarch. As previously mentioned, establishing such a dialogue was a priority for this royal visit, thereby likely justifying such a large sum.

If we look at other maintenance costs a similar pattern seems to emerge.

Item paid for rowghcasting \& playstring of Lafores gate on bothe sides, Newgate and both the frowme gates on bothe sides and for setting vp of scaffoldes $\&$ taking down the same as by thaccomp - ix.li xi.s i.d ${ }^{26}$

Item paid for paynting and gilding the said gates paid to John Phypps and John Kirry painters - xxvi.li xiii.s iiii.d ${ }^{27}$ 
While these costs concern the maintenance of three gates, the sum of over $£ 36$ again is a significant expense. When we look at the locations in relation to the queen's visit, the expenditure becomes clear. One location was Lawford's gate where Thomas Kelke, the mayor of Bristol, greeted the queen; Newgate, like the High Cross, was a location for one of the speeches. ${ }^{28}$ While we do not know whether Frome gate was also a chosen location for one of the orations, its proximity to St Bartholomew's School suggests it was an important site, given that the expense account notes that Elizabeth was entertained at the 'stage at the schole dore'. ${ }^{29}$ The choice to roughcast, plaster, paint, and gild these specific gates again gives strong indication that the landmarks chosen for renovation functioned as important contact points where the discourse between the city and crown could be developed.

Even the smaller charges in the accounts reflect this pattern of contact points with the queen dictating what work should be done.

Item paid for charge of pitching \& repayring of the ways at Lafores gate — iiii. li xii.s viii. $\mathrm{d}^{30}$

Item paid for pitching the streets as appereth by thaccompt — iii.li xviii.s x.d $\mathrm{d}^{31}$

For reasons mentioned above, Lawford's gate is an understandable location for 'pitching', the laying down of new cobble stones. The only other 'pitching' expense is not qualified by a location, thus suggesting that only at Lawford's gate were large sections of the streets repaved, with the rest of the city simply undergoing patch repair work. The disparity between the expenditure for pitching just Lawford's gate and the cost for laying cobbles through the rest of the city epitomizes the highly selective nature of the expenditure on 'general' city maintenance.

Some of the expenses do appear to match up with Cole's suggestion that these 'permanent' costs were necessary, with the monarch's arrival merely setting a target date. The decision to affix the royal and civic coat of arms at the Guildhall, at a cost of over $£ 10$, would most likely have been necessary at some stage regardless of Elizabeth's progress. ${ }^{32}$ On the other hand, the majority of these long-term investment costs illustrate the limitations of Cole's categorization. While all these charges were for the maintenance of the city, Cole's argument seems incomplete, as the expenses indicate that the money was not used only for general civic upkeep. Rather, the expenses involved a highly selective set of improvements which were dictated by the contact locations with the queen. So while they were, as Cole suggests, long-term 
investments, they were not part of regular maintenance costs. By looking at another example of a 'permanent' cost it is possible to emphasize the limitations of Cole's analysis when applied to Bristol. The commissioning of a new pearl-encrusted scabbard for the city's 'swordbearer', at a cost of $£ 49 \mathrm{~s}$ 10d, would surely fall into Cole's 'permanent' costs. ${ }^{33}$ After all, the scabbard continued to be used after this occasion and, indeed, remains one of Bristol's civic treasures to this day. ${ }^{34}$ On the other hand, since the city already possessed at least one other ceremonial sword, we may wonder whether the corporation would have commissioned the scabbard had it not been for the queen's visit. The 'swordbearer' was a key figure in Bristol's civic ceremonies and as such would have been on display at many points during the queen's visit. ${ }^{35}$ This case thus illustrates that while the 'permanent' categorization is useful for analysis, the choice of such investments was directed by the need to provide an optimum setting for dialogue between city and crown.

We may now turn to the temporary costs. This category of expenses, according to Cole, includes payments for entertaining the queen through means which would be of no direct value to the city after her departure. ${ }^{36}$ The progresses used in Cole's study are of a more traditional nature, with the entertainment being made up of a series of small-scale performances which did not cost much to put on. The queen's visit to Bristol, however, was dominated by a lengthy and extremely expensive mock battle. It is thus worth separating the costs of this piece of military theatre, a three-day battle between Peace and War, from the rest of the expenses. The total cost spent on transporting, unloading, and clearing the sand for this mock battle was just under $£ 40$ :

Item paid for sandyng the marshe, reryng of the growndes and levlyng the way — viii.li xv.s ii.d ${ }^{37}$

Item paid for setting vp of postes and rales \& sandyng the way at St Austens Back - vii.li i.s vii.d ${ }^{38}$

Item paid to the lighter men that brought 53 lighters of sand for the streets vi.li xix.s x. $\mathrm{d}^{39}$

Item paid to the hallyeurs for halyng all the said 53 lighters of sand yt 960 fates at i.d per fate - iiii.li v.d ${ }^{40}$

Item to the fillers of the fates with sand - xv.s ii. $\mathrm{d}^{41}$ 
The first three entries here show the cost of sanding three different areas. This division of payments suggests a number of contractors, unlike the payments for working on the gates. Additionally these entries are for a variety of labours: the first two are for the act of sanding, the following two for transportation of sand, and the last for filling up containers for transportation. The absence of names may imply that a large number of labourers were used, as elsewhere the expenses account does tend to name recipients. ${ }^{42}$ The amounts of the payments themselves also suggest a significant number of workers as the daily wage rate for a single labourer at this time was around $8 \mathrm{~d} .{ }^{43}$ The number of payments here and the implication of multiple labourers illustrate the large scale of these preparations. The financial and physical commitment made by using numerous labourers on what was essentially basic scenery for the battle reinforces just how far the corporation was prepared to go to impress the queen.

Additional temporary payments reinforce the significance that the corporation attached to the visit. These costs were unrelated to the mock battle but were incurred purely for winning additional favour with Elizabeth I. A speech describing how the queen's arrival caused citizens 'to ryng their bels' gives information about one such cost. ${ }^{44}$ Naturally one might presume bellringing would incur additional costs, but no mention of this appears in the accounts. This instance exposes a limitation to the mayor's audit books as a source, as it implies that either some of the entertainments were funded separately or simply not recorded at all. On this occasion individual parishes most likely paid for the bell-ringing, given that at other progresses the musicians and bell-ringers were compensated in this way. ${ }^{45}$ We can interpret such a gap in the expenses as potential evidence that the financial dedication to these entertainments was not restricted to the corporation's raised funds but was widespread, with willing citizens making their own contributions for the civic benefit.

The temporary expenses I have discussed to this point, while far from insignificant, were dwarfed by the permanent costs discussed earlier. This was certainly not the case with all the temporary expenses, however. In her study on progresses, Felicity Heal discusses how during Elizabeth I's reign gift-giving became a fundamental aspect of hosting a royal progress. ${ }^{46} \mathrm{Heal}$ argues that the importance of gift-giving grew as people began to base the exchange of gifts on the allegorical significance of the Three Graces. ${ }^{47}$ The proper exchange process involved giving graciously, receiving courteously, and requiting thankfully. ${ }^{48}$ This philosophy of giving and receiving gifts 
empowered the traditional civic gift, since it implied reciprocation. Now when hosts presented their gift they were not just displaying loyalty but were simultaneously asking for the assurance of good lordship from the monarch in return. ${ }^{49}$ Cole's work supports Heal's supposition regarding this heightened significance of the gift by underlining the gift as the greatest expense when hosting a royal visit. ${ }^{50}$ With so much significance associated with the civic gift, it is worth exploring records of such gifts in the Bristol audit books.

Bristol's gift for Elizabeth followed the tradition of the mayor giving money in a purse to the queen. The accounts show that a silk purse was purchased at just over $£ 1$; when given to the queen it contained 200 coins totalling $£ 100.51$ This amount was much higher than was typical. Cole's research discusses the value of gifts with examples of Northampton spending $£ 26$ and Cambridge $£ 16$; only Sandwich’s gift matched that of Bristol. ${ }^{52}$ On the other hand, given that Bristol was one of the largest cities in the country, it would presumably have been expected to produce an appropriately substantial gift. ${ }^{53}$ One must, however, take into consideration the nature of this expense. Unlike the earlier large sums for painting and gilding, this was not a visible investment in the city; it was essentially the direct handing over of $£ 100$. Considering that the resumption of trade had already been agreed prior to the queen's visit this gift can be regarded as a display of gratitude. The extravagance of the gift, moreover, suggests that the corporation wanted to reflect the importance of the immanent treaty and perhaps constructed such a display of wealth to suggest undertones of the financial benefits the queen could expect from her peaceful diplomacy.

While a material gift to the monarch had become an integral part of hosting a progress, gift-giving extended beyond this one offering. In her study, Heal refers to Mary Ratcliffe, the keeper of the queen's jewels, who in 1574 recorded two gifts given to Elizabeth at Bristol, the first of which was a salamander and phoenix jewel from Sir John Young, and the other, a dolphin in mother-of-pearl decorated with gold from Sir John Sherington. ${ }^{54}$ These gifts were not recorded in the audit books as they are most likely to have been from private individuals who, unlike those paying the bell-ringers, were probably soliciting for some piece of personal patronage. Other records of Elizabeth's progress to Bristol mention Lord Burghley receiving a gallon of claret, two gallons of sack, and a large sugar loaf weighing fifty pounds. ${ }^{55}$ While by 1574 giving additional gifts to important members of the queen's retinue was common practice, in this instance the expenses contain no record of these gifts. ${ }^{56}$ The absence of these costs from the accounts could be seen as similar 
to the absence of the additional gifts for the queen, reinforcing this secondary layer to hosting a progress governed not by the corporation's ambitions but by individuals seeking favour. In terms of gifts, the corporation's expenditure shows the continued commitment to crafting an optimum setting for the ceremonial dialogue. While all other studies on progress expenses have shown the gift to the queen as the most expensive outlay, this was not the case in Bristol.

The lack of a petition at the 1574 progress, as we have seen, meant that the corporation had to convey its aspirations for peace through the entertainments themselves. The expenses to be addressed now will illustrate what costs were involved to ensure the desired message was communicated, while confirming both the military capacity and the loyalty of the city. While the mock battle was not an original form of entertainment, Bristol's battle was unlike its predecessors in that it extended over three days, was accompanied by speeches, had some form of plot, and even included audience participation. ${ }^{57}$ Such an elaborate display would be expected to come with an elaborate price tag. Indeed, the cost for simply supplying the soldiers with food, drink, clothes, and ordnance was unprecedented. ${ }^{58}$

The expenses account includes five payments made for corn and serpentine powder, Elizabethan forms of gunpowder. These costs totalled just over $£ 210$ with one of the fees being the largest paid to any one individual in the whole account:

Item paid to Robert Robynson for xxvi C $36 \mathrm{lb}$ of corne and serpentyne powder at 13.d per $\mathrm{lb}-\mathrm{iCxLii.li} \mathrm{xv.s} \mathrm{viii.d}{ }^{59}$

The sum here of $£ 142$, to be spent solely on gunpowder, easily surpasses the value of the queen's gift and this was not even for the full supply. The accounts feature another four instances of such a purchase with one of them being for 'dyverse grocers'. ${ }^{60}$ The spread of these payments over numerous traders is accompanied by a significant range in cost, from the $£ 142$ fee already mentioned to the $£ 1$ and 10 pence paid to William Newton. ${ }^{61}$ These costs underline how important the success of the mock battle was.

Payments for gunpowder were just one cost borne for militarizing the civic display. There were also charges for various types of ordnance. The accounts show purchases of 'Arcabouzes', ${ }^{62}$ small portable guns, of 'morters of Brasse', and of pistols. ${ }^{63}$ By displaying such a variety of weaponry the corporation likely hoped to demonstrate to the queen the extent of their military powers. 
The funding that went into the soldiers' uniforms reinforces our sense of this desire to exhibit military prowess. The accounts lists include several payments for new garments, such as 'Souldwer capps', ${ }^{64}$ but the main cost here came with the purchase of various materials, exemplified here:

Item paid to mr Randall hassall, to Thomas pyttes \& John hort for red cloth for the pike mens Gasskyns — xxvii.li xvi.s vi.d ${ }^{65}$

The significance here is that the corporation was spending another $£ 27$ just to ensure that all the pikemen were wearing red breeches. Not only would the new garments add to the sense of professionalism in the military display but the use of the queen's colours would have been another means to exemplify Bristol's loyalty.

The decision to pour money into a three-day mock battle rather than the more traditional pageantry was by no means random. The corporation presumably chose this option to appeal to the queen because they would have been extremely aware of Elizabeth's potentially fragile position. Having had to overcome both the Ridolfi plot and Northern Rebellion already and with Pope Pius v not only excommunicating her but encouraging the Catholic powers of Spain and France to depose her, Elizabeth's reliance on loyal subjects, capable of offering military support, was patently clear. ${ }^{66}$ We can understand, then, why the corporation dedicated the majority of its budget to a grand piece of military theatre.

Another large payment can be seen with reference to the ships used:

Item paid to Thomas Symons for furnyshing the galleys, Barges and other charges - $\mathrm{xCi}$.li v.s ii.d ${ }^{67}$

Having spent so much on arming the soldiers with various weapons and attiring them, one might question the expense of $£ 91$ to furnish the galleys and ships. With the intended message, however, being one of extensive and loyal military resources, the corporation no doubt regarded the display of Bristol's naval capabilities as essential. Elizabeth would have been well aware of the role Bristol ships played in co-operating with the royal navy and helping her father fight France three decades earlier. ${ }^{68}$ Indeed furnishing these ships was likely so costly because they had to be equipped for war in order to communicate the desired message to the queen. The accounts go on to record the 'ballesting the ffoxe', most likely to be the forty-five ton ship captained 
by Richard White. ${ }^{69}$ Putting the queen face to face with three armed ships in hot pursuit of one another would have undoubtedly been a spectacle not easily forgotten, an ideal method to impress Elizabeth. These costly expenses highlight how significant the mock battle was to the corporation and just how carefully planned it was.

The remaining payments for the mock battle reveal another important aspect of the accounts. By organizing such an elaborate mock battle the corporation incurred a number of expenses payable to significant individuals. One of the greatest beneficiaries appears to be Dominic Chester who for 'his charge of the ii fortes' and some other business received $£ 81 .{ }^{70}$ While Dominic Chester was himself an alderman of Bristol, this was not the case with all the recipients: ${ }^{71}$

Item paid to Captaigne Shute for his travaile who was generall of all the armye - xvi.li xiii.s iiii.d $\mathrm{d}^{72}$

The payment here is for a Captain John Shute, a soldier of the crown. ${ }^{73}$ Considering the desired message to Elizabeth seems to have been Bristol's military capacity, it appears incongruous at first to employ an outsider to function as the general of all the army. What must be realized is that during Elizabeth's reign displays of loyalty had moved on from the days of Henry viI when civic hosts stressed their antiquity and independence. ${ }^{74}$ By 1574 an attitude had shifted from a focus on the abilities of the local community to a focus on how the local community incorporates itself within, and subordinates itself to, the centre. ${ }^{75}$ This culture of loyalty through subordination most likely inspired the hiring of John Shute. While we could interpret his employment simply as recognition of his expertise, the records of 'riding to the court to wyndsor $\&$ sending for captaigne Shute' suggest that there was more to it. ${ }^{76}$ The mock battle itself reflects this means of displaying loyalty, not just by having Elizabeth as the peacemaker but also by having the turning-point in the mock siege coming about after some of the queen's officers helped the forts' defence. ${ }^{77}$ The significance of using the queen's officers is indicated by the $£ 32$ charge, reinforcing the idea that their inclusion was a means to add to the ceremonial message that Bristol was not an independent force but simply part of the national defence under the queen's authority. ${ }^{78}$

The most obvious instance of the corporation using the employment of outsiders as a means of confirming loyalty through subordination involves the very organization of the entertainments. The employment of Thomas 
Churchyard, the soldier-poet and member of Elizabeth's retinue, was by no means conventional. Civic hosts usually employed local schoolmasters to organize entertainments for important events and the corporation sent a strong message of subordination to the crown by outsourcing the scripting and direction of this piece of theatre. ${ }^{79}$ Churchyard's account even recalls how some of the intended orations were not spoken because Mr Dunne, the schoolmaster, 'envied that any stranger should set forth these shoes' ${ }^{80}$ The accounts reflect this decision by the corporation to prioritize the outsider Churchyard over the local Mr Dunne:

Item paid to mr Churchyard for his travayle bothe in the ffortes and concernyng oracions - vi.li xiii.s iiii.d ${ }^{81}$

Item paid to mr Dunne Scholemaster of the Barthilmews toward his charges of his stage at the schole dore - i.li vii.s vi.d ${ }^{82}$

Here we can see that it was Churchyard who was employed to deal with the forts and orations while Dunne was paid only for his stage at the school. Not only is Dunne paid merely a fifth of Churchyard's fee, possibly another motivation behind his alleged prevention of some of the planned speeches, but his payment makes no reference to him organizing a performance, which may imply that he was paid literally for providing the stage. This stark contrast between Churchyard's role and Dunne's epitomizes the tactic exploited by the corporation of displaying loyalty to the crown through subordination to it.

The receipts and expenses accounts recorded in the mayor's audit books reveal how the corporation had stretched its physical and fiscal resources to produce a unique show to ensure their success as civic hosts to the queen. By mirroring the queen's signing of a treaty the corporation was highlighting its appreciation for her good governance while simultaneously reassuring Elizabeth I by displaying an impressive and loyal military force. This whole episode exposes an interesting aspect of civic drama, displaying how it was not just a means of petitioning monarchs but instead how it could be used to thank a monarch for good governance. The sheer scale of these elaborate entertainments, illuminated by the immense costs, would have left those attending, including the queen, with a powerful, lasting impression. The 1581 charter granted to Bristol by Elizabeth I indicates the corporation's success. The preamble to this document states that the charter was being granted to the city partly on the grounds that the city had 'proved its loyalty 
to the Crown', a statement that may at least in part hark back to the 1574 festivities. ${ }^{83}$ These entertainments were an unprecedented form of civic drama at an unprecedented cost, undoubtedly long remembered by all present.

\section{Mayor's Audit Book 9 BRO/F/AU 1/10}

I am grateful to Sally Beth MacLean, associate director and executive editor of the Records of Early English Drama volumes, for permission to reprint this transcription from Pilkinton, REED: Bristol.

The transcription, which I have checked thoroughly myself, follows the spelling, capitalization, and punctuation of the original document, which is contained within the mayor's audit books. Reconstructions of suspensions are in italics; eg, 'paid' for 'p'd'

Receiptes of suche moneys collectyd for the Quenes Majesties enteirteignement In primis received of Trinitie warde the sume of - iC-iiii.li vii.s Item received of Alhalon warde the sume of $-\mathrm{iC}$ lxxiii.li x.s Item received of St mary porte warde the sume of $-\mathrm{xCi}$.li iiii.s vii.d Item received of Redclyf warde the sume of — Lxxi.li ii.s iiii.d Item received of St Ewens warde the sume of $-\mathrm{xCiiii.li} \mathrm{xvii.} \mathrm{viii.d}$ Item received of mr pary of the colledge towardes the raling and sanding of the way at st Austens Back and owenyng the ground sume of - v.li

Item sold the canvas that was left which coveryd the highe crosse when it was in gilting and payntyng wherof half was rotton \& part of it stollon for the sume xxiiii.s iii.d

Item received for the canvas that was left which coveryd the ii ffortes vizt. 159 ells - i.li xix.s ix.d

Item received of Thomas Symons for bordes \& the rest of william Salterns accompt — iiii.li iiii.s vi.d

\section{Moneys borrowed of Sir Thomas Whites accompt for the vse above said to be} repayed to the said accompt

In Primis borrowed out of Sir Thomas Whites accompt the sume of 200.li which was appoynted for corne as apeared by his accompt of ii last yeres past which money is to be repayed to the same accompt as spedelie as convenyentlie may be amounteth - iiC.li 


\section{II4 FRANCIS WARDELL}

Item received owt of Barstaples Chest owt of a bag of 250.li which money is to purchase land, which also is to be repayed and returned to the said chest the sume of - iiCL.li

Sume of this side - CMXCvii.lix.s i.d

Summa totalis of of fines and casualties of the old jury and of collected and of moneys borrowed amounth to the sume of - 1/MCxx.li xvii.s xi.d

The Charges of the Queenes Majesties enterteignement to the citie of Bristoll as ffolowith

In primis paid for charges of gilting \& paynting the highe crosse and making newe benchys as by thaccompt - Lxvi.li xiii.s vii.d

Item paid for rowghcasting \& playstring of Lafores gate on bothe sides, Newgate and both the frowme gates on bothe sides and for setting vp of scaffoldes $\&$ taking down the same as by thaccomp - ix.li xi.s i.d

Item paid for paynting and gilding the said gates paid to John Phypps and John Kirry paynters - xxvi.li xiii.s iiii.d

Item paid for pitching the streets as appereth by thaccompt - iii.li xviii.s x.d

Item paid for setting vp the Quenes Armes \& the towns Armes in Frestone in the yeld hall wall - x.li xiiii.s i.d

Item paid for setting vp a Scaffold at the highe crosse for the Oracion — [blank]. li viii.s iii.d

Item paid for rowghecasting the walls of the yeld halles withowt and washing within the halles - v.li viii.s xi.d

Item paid for riding to the court to wyndsor \& sending for captaigne Shute — iii. li xv.s

Item paid for the purse of gold, Sylver and Silk whoerin the 200 angelettes was presented - i.li xii.s

Item paid for sandyng the marshe, reryng of the growndes and levlyng the way viii.li xv.s ii.d

Item paid for setting vp of postes and rales \& sandyng the way at St Austens Back — vii.li i.s vii.d

Item paid for setting vp a gallery in the marsh for the Quenes Majesties to se the tryumphes - xix.li iiii.s iii.d 
Item paid to the lighter men that brought 53 lighters of sand for the streets — vi.li xix.s x.d

Item to the fillers of the fates with sand - xv.s ii.d

Item paid for mending the way in magdalen lane where the Erle of Lyncoln lay [blank].li vi.s viii.d

Item paid for charges upon Arcabouzes \& drumes \& for an Enseigne with a white crosse - v.li vii.s vi.d

Item paid for charge of pitching \& repayring of the ways at Lafores gate - iiii.li xii.s viii.d

Item paid for ffees and charges to the Quenes clerk of the market \& to the yoman of ye bottells - v.li

Item paid for making the quenes way thrughe Temple mede at her goyng away blank.li xiiii.s iii.d

Item paid for newe making and dressing the Scabbard with pearles — iiii.li ix.s x.d

Item paid to mr Dowting mr Swordberer and to Edward chester for charge riding to ye court at Gloucester - ii.li i.s v.d

Item paid for 26 small barrills for $26 \mathrm{C}$ of corne \& serpentyne powder — blank.li xix.s vi.d

Item paid for the nete charges of casting of 7 morters of Brasse $\&$ making of pestells — iii.li iii.s iii.d

Item paid to Edmond Robertes John hopkyns and to John Sachfiels Captaignes as by their accompt - iCLxxiii.li x.s xi.d

Item paid to Thomas Symons for furnyshing the galleys, Barges and other charges — xCi.li v.s ii.d

Item paid to mighell pepwell for corne powder for calyvers flaskes $\&$ towchis as by his accompt - xvii.li i.s iiii.d

Item paid to $\mathrm{mr}$ John Brown for charges of drume players and for capps for soldiers as by his accompt - xxv.li i.s

Item paid to henry Robertes for capps vitayles \& drynck for Souldiors — vi.li [illegible].s viii.d

Item paid to Robert Robynson for xxvi C $36 \mathrm{lb}$ of corne and serpentyne powder at 13.d per lb - iCxLii.li xv.s viii.d

Item paid to mr domynyck Chester for charges of the ii fortes with other busynes as by his accompt — Lxxxi.li viii.s iiii.d

Item paid to John ffield for his paynes in dressing the marsh — i.li 
Item paid to mr Richard Cole for bockeram and canvas 230 yardes and 138 elles for souldiers dublettes - xiii.li viii.s vi.d

Item paid to mr william Gittons for a piece of brasse for drumes \& planckes as by his accompt - iii.li x.s

Item paid to mr Thomas kelke for 200 Angelettes that he presented to the Quenes majestie - iC.li

Item paid to mr kelke for certeign ffees that he paid to the quenes officers as by his accompt - xxxii.li

Item paid to william Newton grocer for certeign corne powder delyverid to John Sachefield - i.li x.d

Item paid to mr phillip Langley for vytlyng of vi gonners and losse of armour as by his bills — xiii.li iii.s viii.d

Item paid to william Byny for vitling of souldiors goyng and retournyng form the camp as by his bill — i.li

Item paid to Captaigne Shute for his travaile who was generall of all the armye xvi.li xiii.s iiii.d

Item paid to mr Churchyard for his travayle bothe in the ffortes and concernyng oracions - vi.li xiii.s iiii.d

Item paid to william Saltern \& Thomas deconson for charges of the grete ordynance as by their accompt - ix.li xv.s vi.d

Item paid to harry Robertes and John Saunders for Souldwer capps as by thaccompt — iiii.li xix.s

Item paid to Lxxxv pyoners who wrought at the ffortes - iiii.li v.s

Item paid to mr Dunne Scholemaster of the Barthilmews toward his charges of his stage at the schole dore - i.li vii.s vi.d

Item paid to John Amorgan for vi barrills of bere and vi dozen of ale to vityale souldiors - i.li x.s

Item paid to dyverse grocers for vii C Lii lbs $1 / 2$ of cornepowder as by their bill amounteth $752 \mathrm{lb} 1 / 2$ - xLix.li ix.s x.d

Item paid for ballesting the ffoxe and for clensing of harnesse — [blank].li xii.s iiii.d Item paid to mr mayer Sergeantes towards their paynes — i.li vi.s vii.d

Item paid to mr Randall hassall, to Thomas pyttes \& John hort for red cloth for the pike mens Gasskyns — xxvii.li xvi.s vi.d

Item paid to mr Aldworth for loss vpon light Angelettes who was the generall Receyvor — [blank].li xi.s 
Item paid to mr Snygge for losse of planckes and for occupieng of his grete orndnaunce \& reparacion therof — ii.li x.s

Item paid to the lighter men for lighterage of 53 lighters at half lighterage which amounteth to 15. li $6 . s$ - vii.li xvi.s xi.d

Item paid to the hallyeurs for halyng all the said 53 lighters of sand yt 960 fates at i.d per fate - iiii.li v.d

Item paid to the Rakar for haling $35 \mathrm{dd}$ fates of sand owt of the stretes after her majestie was gonne - iii.li x.s

Item paid to $\mathrm{mr}$ stone for losse of angelet iii.s for a barrill of bere iiii.s — [blank]. li vii.s

Item paid to Edward Chester for a bill of parcells silkes and ffrenghe for the men of war at mr Recorders apoyntment — iiii.li i.s vii.d

Item paid to harry Robertes for the rest of Accompt of charges that he layed owt as by $\mathrm{mr}$ kelkes accompt — vi.li i.s viii.d

Summa totalis of all the charges of the Quenes majesties enterteignement 1/M Liii.li xiiii.s xi.d

Summa totalis of the paymentes of the fowrthe quarters with the charges of the Quenes majestie — 1/M Cxxvi.li iii.s iiii.d

\section{Notes}

I wish to thank Evan Jones for his counsel throughout and his continual guidance during the editing process. I would also like to thank Richard Stone for his help during the early stages of research for this article.

1 D. Bergeron, English Civic Pageantry 1558-1642 (London, 1971), 10.

2 M.H. Cole, 'Monarchy in Motion: An Overview of Elizabethan Progresses', in J. Archer, E. Goldring, and S. Knight (eds), The Progresses, Pageants, \& Entertainments of Queen Elizabeth I (New York, 2007), 27.

3 C.E. McGee, 'Mysteries, Musters, and Masque: The Import(s) of Elizabethan Civic Entertainments', in Archer, Goldring, and Knight (eds), Progresses, 108; J.E. Archer and S. Knight, 'Elizabetha Triumphans', in Archer, Goldring, and Knight (eds), Progresses, 3. 
4 Calendar of State Papers: Foreign Series in the Reign of Elizabeth 1572-74 (London, 1876), 337.

5 S. Flavin and E.T. Jones (eds), 'Bristol "Particular" Customs Account, Imports, 1563/4' (University of Bristol, Rose, 2009) < http://hdl.handle.net/1983/1303> (accessed 2 February, 2011).

6 S. Flavin and E.T. Jones (eds), 'Bristol Port Book, Overseas Outwards, 1575/6' (University of Bristol, Rose, 2009) <http://hdl.handle.net/1983/1306> (accessed 2 February 2011).

7 Flavin and Jones, 'Port Books Inwards 1575/6'.

8 Ibid.

9 E.T. Jones, 'The Bristol Shipping Industry in the Sixteenth Century', PhD Thesis (University of Edinburgh, 1998), 133.

10 Information on the occupations of Bristol's council members can be found in the customs accounts mentioned above and a variety of other secondary works and primary sources: P.V. McGrath, The Merchant Venturers of Bristol (Bristol, 1975); J. Vanes (ed.), Documents Illustrating the Overseas Trade of Bristol (Bristol Record Society Publications, xxi, 1979); M. McGregor, Bristol Apprentice Book, vols 1-4, 1566-1593 (Bristol, 1992-94).

11 T. Churchyard, The Firste Parte of Churchyardes Chippes, Containing Twelve Severall Labours (London, 1575), 215-36.

12 C. Haigh, Elizabeth I (London, 1998), 192.

13 Bergeron, English Civic Pageantry, 28.

14 D.H. Sacks, The Widening Gate: Bristol and the Atlantic Economy, 1450-1700 (London, 1993), 187.

15 M.H. Cole, The Portable Queen (Massachusetts, 1999), 103.

16 M. Pilkinton (ed.), REED: Bristol (Toronto, 1997), 89, Appendix, 24.

17 Ibid, 85, Appendix, 19.

18 Cole, The Portable Queen, 105.

19 Ibid, 105.

20 Pilkinton, REED: Bristol, 84, Appendix, 18.

21 Alexandra Shepard, 'White, Sir Thomas (1495?-1567)', Oxford Dictionary of National Biography (Oxford and New York, 2004-), doi:10.1093/ref:odnb/2927.

22 Cole, The Portable Queen, 99.

23 Ibid, 101.

24 Pilkinton, REED: Bristol, 86, Appendix 19.

25 Churchyard, Chippes, 215.

26 Pilkinton, REED: Bristol, 86, Appendix, 19.

27 Ibid. 
28 Sacks, The Widening Gate, 187.

29 Pilkinton, REED: Bristol, 88, Appendix, 20; Millerd: Map of Bristol, Bro 43461/1.

30 Pilkinton, REED: Bristol, 87, Appendix, 20.

31 Ibid, 86, Appendix, 19.

32 Ibid.

33 Ibid, 87, Appendix, 20.

34 M. Williams, Civic Treasures of Bristol (Bristol, 1984), 45.

35 L. Toumlin Smith (ed.), The Maire of Bristowe is Kalendar by Robert Ricart (Camden Society, v, 1872), xii, 61, 74.

36 Cole, The Portable Queen, 99.

37 Pilkinton, REED: Bristol, 86. Appendix, 20.

38 Ibid.

39 Ibid, 87, Appendix, 20.

40 Ibid, 88, Appendix, 23.

41 Ibid, 87, Appendix, 20.

42 Ibid, 87, Appendix, 21.

43 P.J. Bowe, 'Statistican Appendix' in J. Thirsk (ed.), The Agrarian History of England and Wales, vol. 4, 1500-1640 (Cambridge, 1967), 864.

44 Churchyard, Chippes, 217.

45 Cole, The Portable Queen, 100.

46 F. Heal, 'Giving and Receiving on Royal Progress', in Archer, Goldring, and Knight (eds), Progresses, 54.

47 Ibid, 48.

48 Ibid.

49 Ibid.

50 Cole, The Portable Queen, 101.

51 Pilkinton, REED: Bristol, 87, Appendix 20.

52 Cole, The Portable Queen, 103.

53 B.M.S. Campbell, 'Benchmarking Medieval Economic Development: England, Wales, Scotland, and Ireland, c. 1290', Economic History Review (2008), 908.

54 Heal, 'Giving and Receiving on Royal Progress', 55.

55 Cole, The Portable Queen, 102.

56 Cole, 'Monarchy in Motion', 31.

57 Archer and Knight, 'Elizabetha Triumphans', 29.

58 Cole, The Portable Queen, 103.

59 Pilkinton, REED: Bristol, 87, Appendix, 21.

60 Ibid, 88, Appendix, 23.

61 Ibid, 88, Appendix, 22. 
I2O Francis WARDELL

62 Ibid, 87, Appendix, 20.

63 Ibid, 87, Appendix, 21.

64 Ibid, 88, Appendix, 22.

65 Ibid, Appendix, 23.

66 McGee, 'Mysteries, Musters, and Masque', 113.

67 Pilkinton, REED: Bristol, 87, Appendix, 21.

68 E. Jones, 'The Bristol Shipping Industry', 101.

69 Pilkinton, REED: Bristol, 88; Appendix, 23 andhttp://rose.bris.ac.uk/dspace/handle/1983/1305.

70 Pilkinton, REED: Bristol, 87, Appendix, 21.

71 M. Stanford, The Ordinances of Bristol 1506-1598 (Gloucester, 1990), 37.

72 Pilkinton, REED: Bristol, 88, Appendix, 22.

73 E. Lord, 'Shute, John (fl. 1557-1598)', Oxford Dictionary of National Biography (Oxford and New York, 2004-), doi:10.1093/ref:odnb/25484.

74 Sacks, The Widening Gate, 187.

75 McGee, 'Mysteries, Musters, and Masque', 105.

76 Pilkinton, REED: Bristol, 86, Appendix, 20.

77 Churchyard, Chippes, 227.

78 Pilkinton, REED: Bristol, 88, Appendix, 22.

79 McGee, 'Mysteries, Musters, and Masque', 111.

80 Churchyard, Chippes, 236.

81 Pilkinton, REED: Bristol, 88, Appendix, 22.

82 Ibid, 88, Appendix, 23.

83 Bristol Charters, 1509-1899 (Bristol Record Society Publications, xiI, 1946), 125-6. 